ISSN 0258-7122

Bangladesh J. Agril. Res. 33(3) : 597-606, December 2008

\title{
PRODUCTIVITY OF RAINFED MUSTARD IN RELATION TO TILLAGE AND MULCHING
}

\author{
N. A. MONDAL ${ }^{1}$, S.M.A. HOSSAIN ${ }^{2}$, \\ S.U. BHUIYA ${ }^{3}$ AND M. JAHIRUDDIN ${ }^{4}$
}

\begin{abstract}
Field experiments were conducted at the Regional Agricultural Research Station of Bangladesh Agricultural Research Institute, Jessore during rabi (winter) seasons of 1999-2001 to study the tillage and mulching effects on conservation of residual soil moisture, yield attributes and yield of mustard (cv. Daulat.). Three different tillage methods, namely minimum, reduced and conventional tillage were used in the main plots and three different mulch materials, namely rice straw, water hyacinth, black polythene including no mulch were used in the sup-plots. It was observed that reduced tillage and polythene mulch or rice straw mulch conserve more moisture than other tillage methods and mulch application. Tillage practice significantly influenced the dry matter, yield and yield components of mustard. Reduced tillage gave consistently the highest seed yield (969 kg/ha), while minimum tillage gave the lowest seed yield (92 kg/ha). Mulching also resulted in better crop growth and increased yield. Significantly higher seed yield (1164 kg/ha) was recorded from black polythene mulch followed by rice straw mulch $(1089 \mathrm{~kg} / \mathrm{ha})$. The yield of mustard was obtained due to the interaction effects on reduced tillage and polythene mulch followed by conventional tillage and polythene mulch, which was found superior to all other treatments. Results revealed that polythene mulch or rice straw mulch accompanied by reduced tillage was economically profitable for mustard cultivation/production under rainfed condition.
\end{abstract}

Key Words: Rainfed mustard, tillage, mulching.

\section{Introduction}

Crop production in Bangladesh is predominantly based on rainfall and its annual distribution. About $90 \%$ of the total rainfall is received in monsoon (June to September) and in the remaining months (October to May) drought of different degrees occurs in almost all areas of the country (Mondal and Wahhab, 2001; Khatun, 2004). In Bangladesh, drought is a common occurrence almost in each and every crop and the dry land farming is being affected by drought.

Depending on the severity of drought, the estimated yield reduction in Bangladesh varies from 10 to $70 \%$ (BARC, 1990). About $43 \%$ of total

${ }^{1}$ Senior Scientific Officer, BARI, OFRD, RARS, Jessore, ${ }^{2 \& 3}$ Professor, Department of Agronomy, BAU, Mymensingh, ${ }^{4}$ Professor, Department of Soil Science, BAU, Mymensingh, Bangladesh. 
agricultural land in Bangladesh has got irrigation facilities and remaining either under rainfed cultivation during winter season or fallow the next kharif season (Anon., 2002).

Mustard is one of the major oilseed crops that occupy $78 \%$ of the area and contribute nearly $62 \%$ of the total oilseed production in Bangladesh (BBS, 2003). In all the cropping systems, mustard is depended predominantly on the residual soil moisture from the preceding crop. However, per hectare yield of rainfed mustard is low. The poor crop performance of mustard under rainfed condition may be due to lack of inadequate soil and water management practices with reference to soil water shortage in the soil profile. Adequate plant population consistent with available water status and other inputs of crop production is a precondition for maximizing yield. In the case of dry land farming, the use of mulch is beneficial which conserves soil moisture, reduces soil temperature. minimizes evaporation loss and enhances root growth (Allamaras et al., 1977; Gupta, J.P. and Gupta, 1986). The effect of mulch on soil temperature, moisture regime and root growth as well as yield depend on the climatic environment, made of mulch application and quality and quantity of mulch materials. On the contrary, tillage plays a vital role in conservation of soil moisture at different depths in rainfed cultivation. It also improves soil condition by altering the mechanical impedance to root penetration, hydraulic conductivity and holding capacity, which in turn affects plant growth (Dexter, 1989). Since, most of the lands in northern-part of Bangladesh remains fallov in winter season due to shortest of water. In this situation, the use of mulch and tillage method is important for plant growth. Considering scarcity of water, the present experiment was undertaken to find out the suitable tillage methods and mulch application to conserve soil moisture for the better growth and yield of mustard during dry season.

\section{Materials and Method}

The experiment was conducted at the Regional Agricultural Research Station of the Bangladesh Agricultural Research Institute, Jessore during rabi (winter) seasons of 1999-2000 and 2000-2001 under rainfed condition. The soil was silt loam (Old Ganges Alluvial Sediment) in texture belonging to Gopalpur series (AEZ-11) harvesting $\mathrm{pH}$ (5.8 to 7.8), organic matter (1.25 to $2.15 \%$ ), total nitrogen $(0.080 \%)$, available phosphorus (13 ppm), exchangeable potassium (2 $\mathrm{meq} / 100 \mathrm{~g}$ ) and available sulphur (12 ppm). The crop received $128 \mathrm{~mm}$ in 19992000 and $189 \mathrm{~mm}$ in 2000- 2001 during crop growth period. Mean maximum and minimum air temperatures were 28.98 and $16.07^{\circ} \mathrm{C}$ in $1999-2000$ and 30.10 and 15.19 in 2000-2001, respectively, during crop season.

The experiment consisted of 3 different tillage methods viz., minimum tillage (one ploughing followed by laddering), reduced tillage (two ploughings followed 
by laddering) and conventional tillage (4 ploughings followed by laddering) and 3 different mulch materials viz., rice straw (cover on the soil surface @ $2.5 \mathrm{t} / \mathrm{ha}$, water hyacinth (cover on the soil surface @ 2.0 t/ha) and black polythene (cover on the soil surface $0.05 \mathrm{~mm}$ thickness) including no mulch. The trial was laid out in split plot design with four replications. The dimensions of individual plots were $4 \mathrm{~m} \times 3 \mathrm{~m}$. Tillage treatments were placed in the main plots and mulch treatments in the sub-plots. A fertilizer dose of 25-40-25-2-1 kg NPKSZnB/ha was applied in the field as urea, triple super phosphate, muriate of potash, gypsum, zinc sulphate and boric acid, respectively. All fertilizers were applied at the time of final land preparation and incorporated with the soil. Mustard seeds (cv. Daulat) were sown in lines $(30 \mathrm{~cm}$ x 10cm) on 15 November in 1999 and 13 November in 2000. Soil samples were collected at a depth of $0-15 \mathrm{~cm}$ and $16-30$ $\mathrm{cm}$ from soil to maturing determined by over dressing the samples at $105^{\circ} \mathrm{C}$ for 24 hours. Profile soil temperature of the experimental plots also was monitored at 10-day intervals in $0-15 \mathrm{~cm}$ soil depth at 12 to 1 noon. Plant protection measure was taken whenever needed. Seed yield and yield contributing characters of 10 days interval of mustard were collected at harvest. Data on different parameters were subjected to analysis of variance and the means were compared by DMRT at $5 \%$ level of probability.

\section{Results and Discussion}

\section{Soil moisture and soil temperature regime}

Soil moisture percentage of mustard trial varied among the tillage methods and mulch materials. Soil moisture in the tilled soil under cropping decreased at higher rates initially followed by slower rates (Fig. 1). In tilled and unfilled soils, the maximum moisture was lost from the surface layer $(0-15 \mathrm{~cm})$. The amount of moisture loss from a well tilled or minimum tilled plots was almost similar irrespective of depth. Soil moisture of well tilled and minimum tilled plots decreased slowly and steadily in both the years. Soil moisture loss pattern varied appreciably due to variation of soil depths among the mulch materials (Fig. 2). During initial stage, evaporation was mostly governed by the external evaporation or by the soil hydraulic properties. In no mulch, soil moisture loss was rapid initially at both soil depths and then it changed steadily but slowly. Apparently the drying of surface soil without mulch cover was quicker in comparison with minimum tilled soil. The quick drying is perhaps due to increased radiant energy available for evaporation on rough soil surface. The soil moisture content remained fairly high in black polythene mulch followed by rice straw and water hyacinth mulch (Fig. 2). The soil moisture content was slightly higher at soil depth of $16-30 \mathrm{~cm}$ than at $0-15 \mathrm{~cm}$ depth under both mulch and no mulch conditions. Mulch helped keep the surface evaporation minimal. Considerable variation in soil temperature was also observed between tillage 
methods and mulch conditions (Fig. 3). Soil temperature was slightly higher in minimum tillage than in the reduced and conventional tillage. Soil temperature was higher under no mulch condition. Temperature was lower under black polythene and rice straw mulch followed by water hyacinth mulch. The reduction in soil temperature under polythene and rice straw mulch might be due to the higher albedo of the black polythene and rice straw mulch which might have incidental solar radiation and decreased the amount of downward transmission of heat. The increase of soil temperature of the surface soil without mulch was quicker compared to tilled soil.
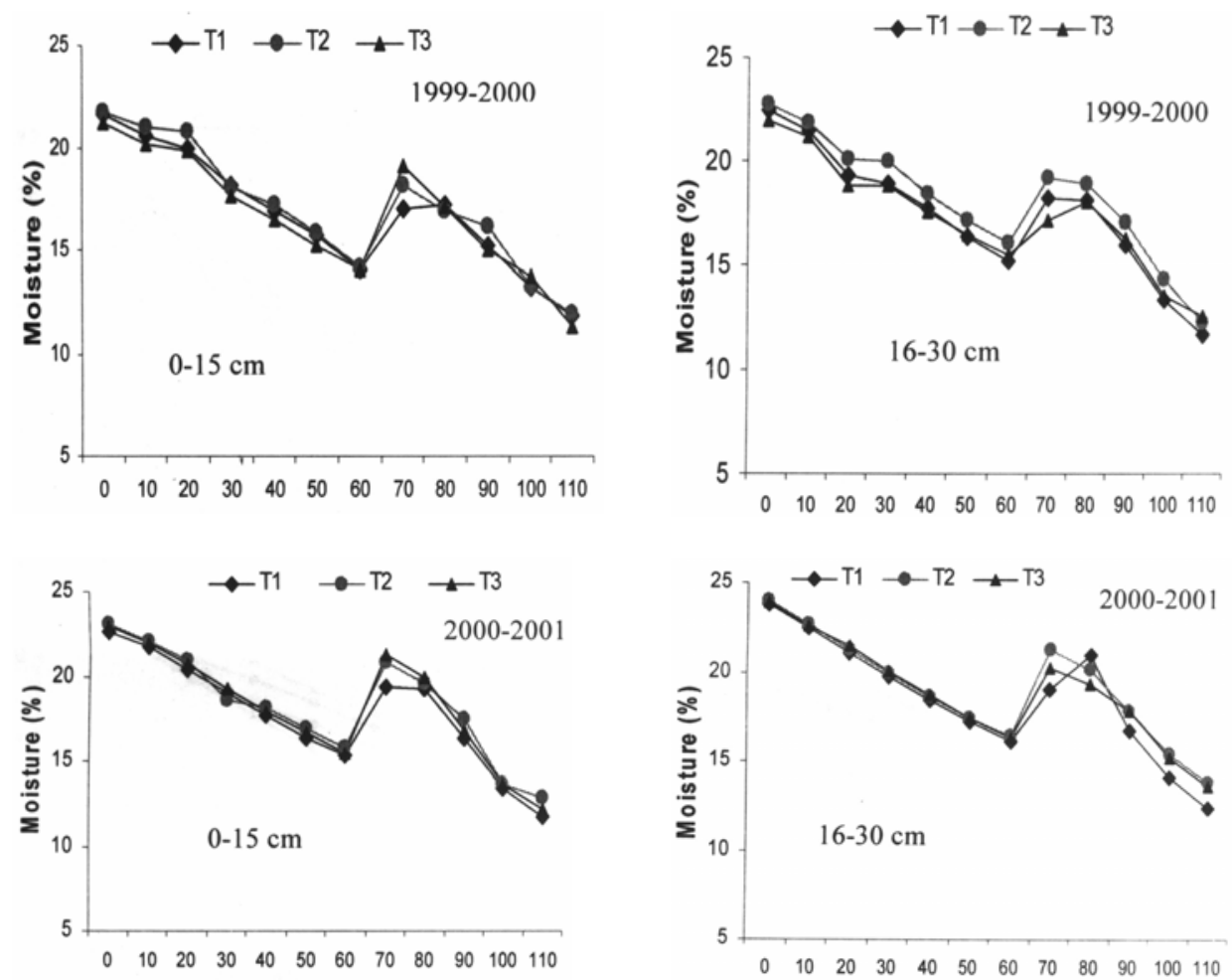

Days after sowing

Days after sowing

Fig. 1. Effect of tillage on soil moisture content over the growing period of mustard during 1992-2001 at 0-15 cm and 16-30 cm depths $\left(\mathrm{T}_{1}=\right.$ Minimum tillage, $T_{2}=$ Reduced tillage and $\mathrm{T}_{3}=$ Conventional tillage) 

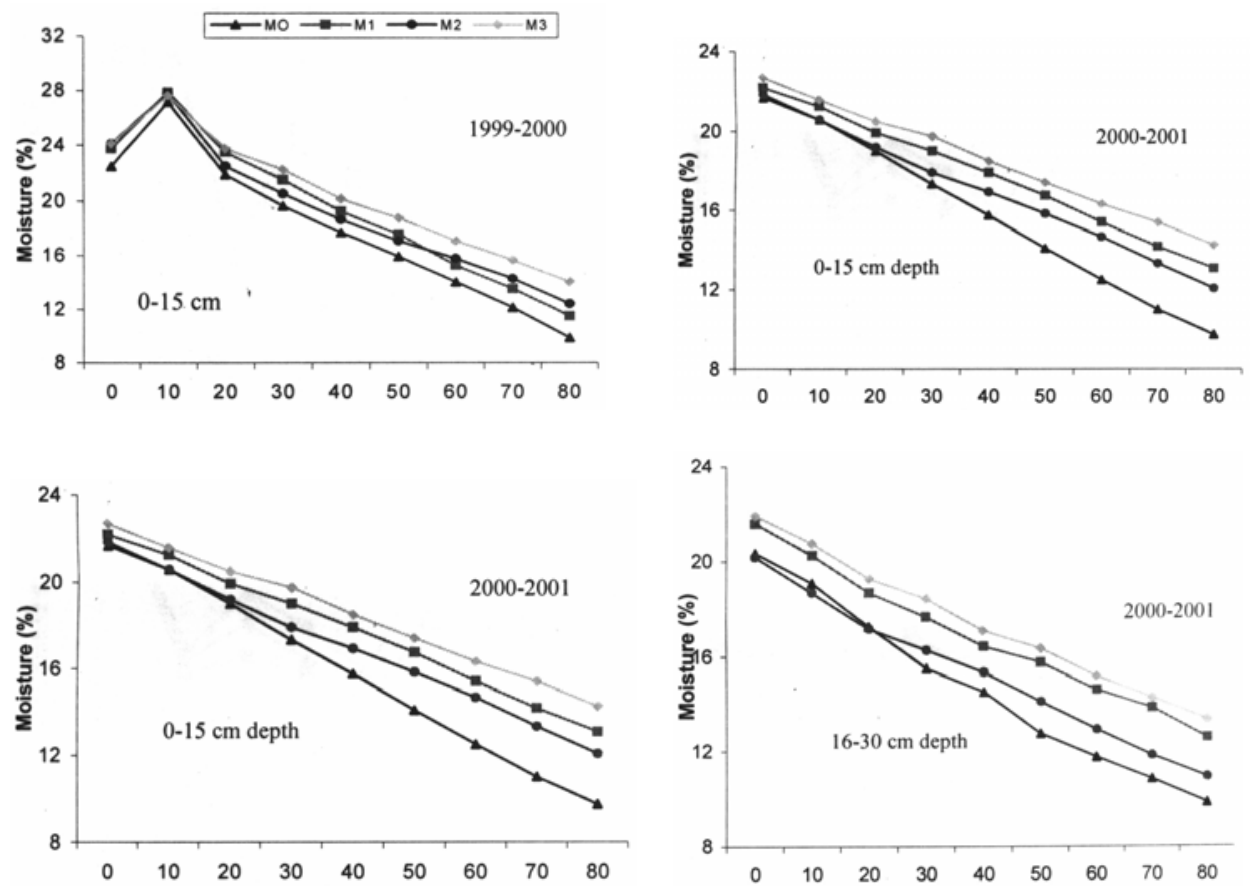

Days after sowing

Days after sowing

Fig. 2. Effect of mulch on soil moisture content over the growing period of mustard duing $1999-2001$ at $0-15 \mathrm{~cm}$ and $16-30 \mathrm{~cm}$ depths, $\left(\mathrm{M}_{0}=\right.$ No mulch, $\mathrm{M}_{1}=$ Rice straw, $\mathrm{M}_{2}=$ water hyacinth, $\mathrm{M}_{3}=$ Black polythene mulch)

\section{Dry matter production}

Tillage methods were found to have significant influence on dry matter (DM) plant of mustard at 45 and 65 DAS and at maturity in 2000-2001 only (Table 1). The highest DM reduced tillage followed by that in conventional tillage. Significantly the lowest DM was obtained from minimum tillage methods except 25 DAS. Different mulching significantly influenced the DM plant of mustard throughout the growing period except at 25 DAS in 2000-2001 (Table I). However, DM of mustard increased with the advancement of time irrespective of mulch practices. Initial rate of increase was very low, but after 25 DAS there was a rapid increase of dry matter and continued upto maturity. Black polythene mulch showed highest DM followed by rice straw mulch irrespective of growth stags. Black polythene mulch produced the highest DM than the others mulches possibly due to day time soil temperature reduction and improved the conservation of soil moisture. The lowest DM/plant was recorded from no-mulch treatment. 
Table 1. Pooled value of dry matter production of mustard over time as affected by tillage and mulching.

\begin{tabular}{ll|l|l|l}
\hline \multicolumn{1}{c}{ Treatments } & 25 DAS & 45 DAS & 65 DAS & Maturity \\
\hline Tillage & & & \\
Minimum tillage & $0.21 \mathrm{~b}$ & $2.13 \mathrm{c}$ & $5.90 \mathrm{~b}$ & $6.68 \mathrm{c}$ \\
Reduced tillage & $0.22 \mathrm{a}$ & $2.22 \mathrm{~b}$ & $6.63 \mathrm{a}$ & $8.72 \mathrm{a}$ \\
Conventionaltillage & $0.21 \mathrm{~b}$ & $2.31 \mathrm{a}$ & $6.71 \mathrm{a}$ & $8.3 \mathrm{lab}$ \\
Mulching & & & & \\
Nomuich & $0.21 \mathrm{~b}$ & $1.93 \mathrm{c}$ & $5.25 \mathrm{c}$ & $6.62 \mathrm{c}$ \\
Rice straw mulch & $0.22 \mathrm{~b}$ & $2.27 \mathrm{~b}$ & $6.73 \mathrm{~b}$ & $8.3 \mathrm{lb}$ \\
Water hyacinth miilch & $0.21 \mathrm{~b}$ & $2.14 \mathrm{~b}$ & $5.96 \mathrm{c}$ & $7.43 \mathrm{c}$ \\
Black polythene mulch & $0.29 \mathrm{a}$ & $2.56 \mathrm{a}$ & $7.7 \mathrm{Ia}$ & $9.48 \mathrm{a}$ \\
\hline
\end{tabular}

Figures in a column having same or without letter(s) do not differ significantly at $5 \%$ level of probability, DAS = Days after sowing.
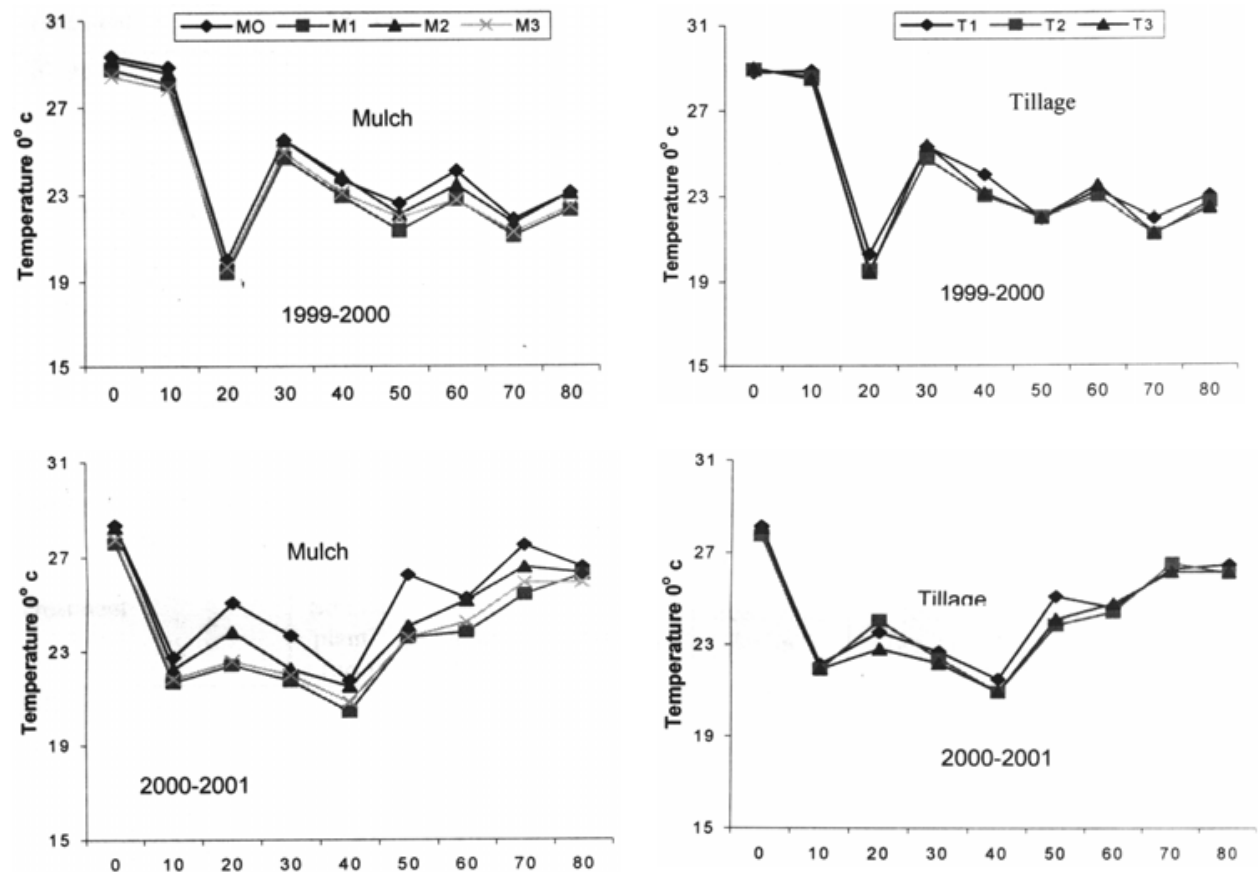

Days after sowing

Days after sowing

Fig. 3. Effect of mulch on soil temperature over the growing period of mustard during 1999-2001 ( $\mathrm{M}_{0}=$ No mulch, $\mathrm{M}_{1}=$ Rice straw mulch, $\mathrm{M}_{2}=$ water hyacinth, $\mathrm{M}_{3}=$ Black polythene mulch and $\mathrm{T}_{1}=$ minimum tillage, $\mathrm{T}_{2}=$ Reduced tillage and $\mathrm{T}_{3}=$ Conventional tillage) 


\section{Effect of tillage method}

Tillage methods significantly influenced number of siliquae/plant, seeds/siliqua and seed yield and dry weed biomass. Tillage methods followed to show significant influence of 1000-seed weight and straw yield (Table 2). Number of siliquae/plant and seeds/plant produced with conventional tillage and reduced tillage were statistically identical but both the tillage methods produced significantly higher siliquae and seeds/plant than minimum tillage. Among the different tillage practices, the highest seed yield $(969 \mathrm{~kg} / \mathrm{ha})$ was obtained with reduced tillage. Reduced tillage have led to more moisture conservation and increased water uptake and nutrient by the plant and consequently resulted high siliquae/plant and seeds siliqua and higher grain yield. Significantly the lowest yield were obtained from minimum (921 kg/ha and conventional tillage (948 $\mathrm{kg} / \mathrm{ha}$ ), but these two tillage methods were statistically identical. This result might be due to less root growth as well as less nutrient uptake which caused lower siliquae/plant and less number of seeds/siliqua and ultimately resulted in lowest seed yield. Weed biomass was also significantly influenced by tillage methods (Table 2). Minimum tillage produced the highest dry weed biomass and it was significantly different from reduced and conventional tillage. However, weed biomass obtained from reduced tillage was at par with conventional tillage. This result might have been due to higher weed population in minimum tillage methods than other tillage methods. Similar results were reported by Quddus (1989) in wheat crop.

Table 2. Pooled value of yield attributes, seed yield and weed biomass of mustard as affected by tillage and mulching.

\begin{tabular}{|c|c|c|c|c|c|c|}
\hline Treatments & $\begin{array}{c}\text { Siliquae/ } \\
\text { plant }\end{array}$ & $\begin{array}{l}\text { Seeds } \\
\text { siliqua/ }\end{array}$ & $\begin{array}{c}1000 \text {-seed } \\
\text { wt (g) }\end{array}$ & $\begin{array}{c}\text { Seed yield } \\
\text { (kg/ ha) }\end{array}$ & $\begin{array}{c}\text { Straw (kg/ } \\
\text { ha) }\end{array}$ & $\begin{array}{c}\text { Dry weed } \\
\text { biornass } \\
\text { (kg/ ha) }\end{array}$ \\
\hline \multicolumn{7}{|l|}{ Tillage } \\
\hline $\begin{array}{l}\text { Minimum } \\
\text { tillage }\end{array}$ & 75.41c & $11.31 \mathrm{~b}$ & 2.34 & $921 b$ & 2306 & 658a \\
\hline Reduced tillage & 91.84ab & $13.09 a$ & 2.56 & $969 a$ & 2355 & 494b \\
\hline $\begin{array}{l}\text { Conventional } \\
\text { tillage }\end{array}$ & $105.84 a$ & $13.12 \mathrm{a}$ & 2.41 & $948 b$ & 2383 & $482 b$ \\
\hline \multicolumn{7}{|l|}{ Mulching } \\
\hline Nomuich & $69.66 c$ & $11.62 b$ & $2.25 b$ & $835 c$ & $1941 c$ & $675 a$ \\
\hline $\begin{array}{l}\text { Rice } \quad \text { straw } \\
\text { mulch }\end{array}$ & 93.83ab & $12.62 a$ & $2.54 a$ & 1089ab & $2518 a$ & $5 \mathrm{l} 2 \mathrm{~b}$ \\
\hline $\begin{array}{l}\text { Water hyacinth } \\
\text { mulch }\end{array}$ & 87.83c & $12.02 \mathrm{a}$ & 2.37ab & $998 b$ & $2237 b$ & 593ab \\
\hline $\begin{array}{l}\text { Black } \\
\text { polythene } \\
\text { mulch }\end{array}$ & 104.79a & $13.00 \mathrm{a}$ & $2.58 a$ & 1164a & $2697 a$ & 397d \\
\hline
\end{tabular}

Figures in a column having same or without letter(s) do not differ significantly at 5\% level of probability. 


\section{Effect of mulching}

Number of siliquae/plant, seeds/siliqua, 1000-seed weight, seed yield, straw yield and dry weed biomass of mustard were significantly influenced by different mulch treatments (Table 2). Application of polythene mulch produced significantly highest straw yield, siliquae/plant, seeds/siliqua, 1000-seed, seed yield and straw yield of mustard followed by rice straw mulch. The lowest yield of mustard was recorded in no-mulch treatment. The reason for high yield in polythene and straw mulch treatments might be due to lower soil temperature and conserves more moisture. Yield of mustard increased in black polythene and rice straw mulch over no mulch to the extent 39\% and 30\%, respectively. Similar results were reported by Duncan et al. (1992) and Marumota et al. (1991). They stated that polythene mulch conserved soil moisture and increased root activity. Sharma et al. (1985) and Mondal et al. (2003) also reported that straw mulch was more effective in mustard than soil mulch. On the contrary, the highest dry weed biomass was found in no mulch followed by water hyacinth mulch. Polythene mulch produced the lowest weed biomass. This might be due to preventing of the rapid development of weeds during early growth stages. Similar results were reported by Mondal et al. (2003) and Midmore et al. (1984). They stated that mulch was capable of reducing certain species of both mono and dicotyledonous weeds. Moreover, application of black polythene emulsion (PE) film was very effective for weed control as stated by Lal (1974) maize crop and Ayanaba and Okigbo (1974).

\section{Interaction between tillage methods and mulching}

Interaction effect between tillage methods and mulching did not show any significant effect for any of the characters under study except the seed yield (Table 3). The highest seed yield was recorded from the treatment combination of reduced tillage with black polythene mulch (1218 kg/ha) followed by reduced tillage with rice straw $(1108 \mathrm{~kg} / \mathrm{ha})$ and conventional tillage with black polythene mulch (1194 kg/ha). The reason for higher yield in the black polythene mulch might be due to decreased soil temperature and diurnal temperature oscillation and more efficient conservation of water which favoured growth of the crops. The lowest yield was recorded in no- mulch irrespective of tillage methods. 
Table 3. Interaction effect of tillage and mulching on seed yield of mustard (Pooled).

\begin{tabular}{l|l|l}
\hline \multicolumn{1}{c}{ Interaction of tillage and mulching } & \multicolumn{1}{c}{$\begin{array}{c}\text { Seed yield } \\
(\mathrm{kg} / \mathrm{ha})\end{array}$} & $\begin{array}{c}\text { Gross return } \\
(\mathrm{Tk} . / \mathrm{ha})\end{array}$ \\
\hline Minimum tillage x No mulch & $791 \mathrm{e}$ & 12260 \\
Minimum tillage x Rice straw mulch & $1002 \mathrm{~d}$ & 15531 \\
Minimum tillage x Water hyacinth mulch & 10l3bc & 15701 \\
Minimum tillage x Black polythene mulch & $1027 \mathrm{bc}$ & 15918 \\
Reduced tillage x No mulch & 780e & 12090 \\
Reduced tillage x Rice straw mulch & 11 O8ab & 17174 \\
Reduced tillage x Water hyacinth mulch & 1 023bc & 15856 \\
Reduced tillage x Black polythene mulch & $1218 \mathrm{a}$ & 18879 \\
Conventional tillage x No mulch & $787 \mathrm{e}$ & 12198 \\
Conventional tillage x Rice straw mulch & lOS6bc & 16368 \\
Conventional tillage x Water hyacinth mulch & $958 \mathrm{~cd}$ & 14849 \\
Conventional tillage x Black polythene mulch & 11 94a & 18507 \\
\hline
\end{tabular}

Figures in a column having same or without letter(s) are not significantly different at 5\% level of probability.

\section{Economic evaluation}

In economic point of view, reduced tillage with water hyacinth mulch showed higher gross margin, benefit-cost ratio and marginal rate of return followed by straw mulch. In other words, considering above all the situations, reduced tillage with straw mulch gave better performance due to its easy availability.

Table 4. Cost and return analysis of mustard as affected by tillage and mulching (Pooled).

\begin{tabular}{l|l|l|l|c|c|cc}
\hline \multicolumn{1}{c|}{ Treatments } & $\begin{array}{c}\text { Seed } \\
\text { yield } \\
(\mathrm{kg} / \mathrm{ha})\end{array}$ & $\begin{array}{c}\text { Straw } \\
\text { yield } \\
(\mathrm{kg} / \mathrm{ha})\end{array}$ & $\begin{array}{c}\text { Gross } \\
\text { return } \\
(\mathrm{Tk} / \mathrm{ha})\end{array}$ & $\begin{array}{c}\text { Total } \\
\text { variable } \\
\text { cost } \\
(\mathrm{Tk} / \mathrm{ha})\end{array}$ & $\begin{array}{c}\text { Gross } \\
\text { margin } \\
(\mathrm{Tk} / \mathrm{ha})\end{array}$ & $\begin{array}{c}\text { Benefit } \\
\text { cost } \\
\text { ratio }\end{array}$ & $\begin{array}{c}\text { Margina1 } \\
\text { rate of } \\
\text { return }\end{array}$ \\
\hline Minimum tillage & 921 & 2306 & 14429 & 9225 & 6204 & 1.67 & - \\
Reducedtillage & 969 & 2355 & 16378 & 10560 & 5637 & 1.53 & 0.58 \\
$\begin{array}{l}\text { Conventional tillage } \\
\text { No mulch }\end{array}$ & 984 & 2383 & 15886 & 11020 & 4866 & 1.44 & 0.25 \\
$\begin{array}{l}\text { Rice straw mulch } \\
\text { Water hyacinth mulch }\end{array}$ & $\mathbf{8 3 5}$ & 1941 & 13929 & 7520 & 6393 & 1.85 & - \\
$\begin{array}{l}\text { Black polythene } \\
\text { mulch }\end{array}$ & 1164 & 2518 & 18138 & 10120 & 8019 & 1.79 & 1.63 \\
\hline
\end{tabular}

Variable cost $=$ Cost incurred in fertilizer, seed purchase and labour

Price:

Mustard seed $=15.50 \mathrm{Tk} . / \mathrm{kg}$, Mustard straw $=0.50 \mathrm{Tk} . / \mathrm{kg}$, Black polythene=52.00 Tk $/ \mathrm{kg}$, Urea $=6.00 \mathrm{Tk} . / \mathrm{kg}, \mathrm{TSP}=12.00 \mathrm{Tk} . / \mathrm{kg}, \mathrm{MP}=8.00 \mathrm{Tk} . / \mathrm{kg}$, Sulpher $3.00 \mathrm{Tk} . / \mathrm{kg}$. ,= Zinc $60.00 \mathrm{Tk} . / \mathrm{kg}$, Boron= $120.00 \mathrm{Tk} . / \mathrm{kg}$. 


\section{Conclusion}

Two years' study revealed that reduced tillage with black polythene mulch or straw mulch during dry season favoured yield attributes which eventually resulted in high yield of mustard.

\section{References}

Allamaras, R.E., E.A., Hallauer, W.U Nelson, and S.S.D. Evans, 1977. Surface energy balance and soil thermal property modification by tillage induced soil structure. Tec. Bull. 306. Univ. of Minnesota.

Anonymous. 2002. Irrigation area in Bangladesh. National minor irrigation census (NMIC). Ministry, of Agric., Govt. People’s Repub. of Bangladesh.

Ayanaba, A. and B.N. Okigbo, 1974. Mulching for improved soil fertility. Proc. FAO/SIDA Expert Consultation Meeting on Organic Materials as Fertilizers. IITA, Ibadan, Nigeria.

BARC (Bangladesh Agricultural Research Council). 1990. Drought in Bangladesh Agriculture and Irrigation Schedule in Major Crops. p. 15.

BARC (Bangladesh Agricultural Research Council). 1997. Fertilizer Recommendation Guide. Bangladesh Agril. Res. Coun.. Air Port Road, Farm Gate, Dhaka. pp. 44-61.

Dexter, A.R. 1989. Soil mechanics relation to tillage implements and root peretration in lowland soils. In Soil Physics and Rice. Int. Rice Res. Inst., 105 Banes, Philippines. pp. 261-281.

Duncan, R.A., J.J. Stapleton, and M.V. Mckenry, 1992. Establishment of orchards with black polythene film mulching. J. Nematology 24: 68 1-687.

Gupta, J.P. and G.K. Gupta, 1986. Effect of tillage and mulching on soil environment under arid condition. Soil \& Tillage Res. 7: 233-240.

Khatun, F. 2004. Cultivation procedures of BARI Sarisha-11. Krishi Katha. 64(8): 264-265.

Lal, R. 1974. Soil temperature, soil moisture and maize yield from mulched and unmuiched tropical soils. Plant and Soil. 40: 129-143.

Manalo, B.E. 1976. Agroclimatic Survey of Bangladesh. BRRI, Dhaka /IRRI, Manila. p.75.

Marumota, T., M., Aoki, Y., Suzuki, T., Kusaka, J.C.W. Kheng, and T. Higushi, 1991. Effect of rhizosphere conditions on the growth of straw berry. Bulletin 39. Facult. Agric.. Yamaguchi Univ., Yamaguchi. pp. 23-25.

Midmore, D.J., D. Berrios, and J. Roca, 1984. Potato (Solanum spp.) in the hot tropics. I. Influence of mulches on soil temperature, soil moisture, weed growth and crop development and yield in contrasting environments. Field Crops Res. 15: 89-96.

Mondal, N.A., S.M.A., Hossain, M.S.U. Bhuiya, and M. Jahiruddin, 2003. Performance of dry land crops as influenced by mulching and tillage. Ph.D. Dissertation, Dep. Agron., Bangladesh Agril. Univ., Mymensingh.

Mondal, M.R.I. and M.A. Wahhab. 2001. Production Technology of Oilcrops. Oilseed Research Centre, BARI. P. 111.

Quddus, M.A. 1989. Weed infestation and performance of wheat as affected by tillage and weed control practices. M.Sc. (Ag.) Thesis in Agron. Bangladesh Agril. Univ. Mymensingh.

Sharma, R.A., G.P. Verma, and R.K. Gupta 1985. Modification of evaporation from vertisol by straw mulch. J. Indian Soc. Soil Sci. 13: 383-386. 